\title{
THE INFLUENCE OF ORGANIZATIONAL CULTURE AND DISCIPLINE ON ORGANIZATIONAL PERFORMANCE THROUGH ORGANIZATIONAL CITIZENSHIP BEHAVIOR IN THE INSPECTORATE OF BEKASI CITY INDONESIA
}

Nita Desi Rianawati

Student Master of Management

Universitas Krisnadwipayana Jakarta

PO BOX 7774/Jat Cm 13077 Jakarta

Email:nitadesih@gmail.com

Indonesia

Suharto

Associate Professor

Universitas Krisnadwipayana Jakarta

PO BOX 7774/Jat Cm 13077 Jakarta

Email: Suhartofe.unkris@gmail.com

$$
\text { Indonesia }
$$

Djoko Setyo Widodo

Lecturer

Universitas Krisnadwipayana Jakarta

PO BOX 7774/Jat Cm 13077 Jakarta

Email:djokosetyowidodo@gmail.com

Indonesia

\section{ABSTRACT}

This study aims to determine the effect of organizational culture and discipline on organizational performance simultaneously, determine the influence of organizational culture on organizational performance partially, determine the effect of discipline on organizational performance partially, determine the effect of organizational citizenship behavior on organizational performance partially, know the influence of culture organization on performance through organizational citizenship behavior and know the effect of discipline on organizational performance through organizational citizenship behavior variables. The study was carried out at the Bekasi City Inspectorate Organization. Sampling uses a saturated sample involving 86 employees in all parts of the organization. Data analysis uses path analysis.

Based on data analysis, it is known that organizational culture variables partially influence organizational performance. $T$ value of 5.055. The significance value is 0.00 . This significant value is smaller than 0.05 . The value of $r$ squared is 0.233 . This means that the influence of organizational culture variables on performance by $23.3 \%$ and the rest is influenced by other variables not included in the equation model.

Discipline variables partially affect organizational performance. T value of 7.282. The significance value is 0.00 . This significant value is smaller than 0.05 . The value of $r$ squared is 0.387 . This means that the influence of disciplinary variables on organizational performance is $38.7 \%$ and the rest is influenced by other variables not included in the equation model.

The variable of organizational citizenship behavior partially influences organizational performance. $T$ value of 14.834. The significance value is 0.00 . This significant value is smaller than 0.05 . The value of $r$ squared is 0.724 . This means that the influence of organizational culture variables on organizational performance by $72.4 \%$ and the rest is influenced by other variables not included in the equation model.

The influence of organizational culture on organizational performance is 0.483 . The influence of organizational culture on performance through organizational culture is $0.614 \times 0.851=0.5191$. In this case, the indirect effect is greater than the direct effect so it can be said that the variable of organizational citizenship behavior as an intervening variable.

The direct effect of discipline on organizational performance is 0.622 . While the influence of discipline on organizational performance through organizational citizenship behavior is $0.762 \times 0.851=0.648$. In this case, the direct effect is smaller than the indirect effect so it can be said that the variable of organizational citizenship behavior as an intervening variable. 


\section{Introduction}

Organizational performance is measured not only in terms of financial concepts but also in non-financial terms. Performance can be measured by productivity, quality, and consistency and so on. On the other hand organizational performance measures results, levels of behavior and normative, education and the resulting concepts including management development (Richard,2002). Organizational performance can be caused by a variety of factors including organizational culture, discipline of working employees and organizational citizenship behavior.

Organizational culture is a system of shared meanings shared by members of an organization that distinguishes the organization from other organizations. Organizational culture is a system of values obtained and developed by the organization and the basic habits and philosophies of its founders, which are formed into rules that are used as guidelines in thinking and acting in achieving organizational goals. A culture that grows to be strong can spur the organization towards better development. Mas'ud (2004), states that organizational culture is a system of meanings, values, and beliefs shared in an organization that is a reference for acting and differentiating one organization from another organization. The organizational culture then becomes the identity or the main character of the organization that is maintained and maintained.

Discipline also influences organizational performance. Discipline is the most important operative function of human resource management because of the better employee discipline, the higher the work performance achieved. Fathoni (2009) said that discipline is one of the important operative functions because of the higher the discipline of an employee, the higher the work performance. While Davis (in Mangkunegera, 2011:129) argues that "discipline is management actions to enforce organization standards". Discipline is a form of control so that the execution of employees' work is always within the corridor of applicable laws and regulations.

In terms of organizational effectiveness, individuals in a team need to have supportive behavior. These behaviors are not only behaviors that fit their role but are expected to be able to bring up the extra-role behavior of the individual so that the teamwork can be more solid and can work optimally for the organization (Khrisnan 2008). This is called organizational citizenship behavior. Organizational citizenship behavior can affect organizational performance. Organizational behavior (OB) is a study of human behavior in an organization and how the behavior impacts the organization.

\section{Literature Review}

\section{Organizational Culture}

Robbins (2003) states that organizational culture is a system of shared meanings within an organization that determines to a greater extent how employees act. Organizational culture is a value system that is believed by all members of the organization and is studied and applied and developed on an ongoing basis that functions as a whole system. Robbins (2003) states: organizational culture refers to a system of shared meaning held by members that distinguish the organization from other organizations. This system of shared meaning is, on closer analysis, a set of key characteristics that the organization value. Furthermore, Robbins (2003) argues that: "Organizational culture as the dominant values disseminated in the organization is used as an employee work philosophy that guides the organizational policies in managing employees and consumers.

Organizational culture as a set of values and norms that control organizational members interact with others and with suppliers, consumers, and other people outside the organization. Organizational culture consists of the final state that the organization strives to achieve (terminal values) and models driving organizational behavior (instrumental values). Ideally, instrumental value helps organizations achieve terminal goals. Different organizations have different cultures because they process different terminal and instrumental value arrangements.

Organizational culture has a broad meaning. According to Dessler (2006), organizational culture is a characteristic of the values, traditions, and behavior of employees in a company. According to Luthans (2000), organizational culture is the norms and values that direct the behavior of organizational members. Each member will behave following the prevailing culture to be accepted by his environment.

Schein in Luthan (2000) defines organizational culture as a pattern of basic assumptions that are found, created, or developed by a particular group with the intention that organizations learn to overcome or overcome the problems that arise due to external adaptation and internal integration that has been running good enough, so it needs to be taught to new members 


\author{
E-ISSN: 2469-6501 \\ VOL: 6, ISSUE: 2 \\ February/2020 \\ DOI:10.33642/fjbass.v6n2p5 \\ https://ijbassnet.com/
}

as a correct way to understand, think and feel comfortable with these problems. Organizational culture is defined as a cognit ive framework that includes attitudes, values, norms and shared expectations shared by organizational members (Baron and Greenberg, 2000). Organizational culture is related to the context of organizational development, meaning that culture is rooted in the history of the organization, believed together and not easily manipulated directly (Schneider, 1996, in Cahyono 2005).

According to Stoner (1996) culture is a complex combination of assumptions, behavior, stories, myths, metaphors, and various other ideas that become one to determine what it means to be a member of a particular society. Organizational culture or corporate culture is often interpreted as values, symbols that are understood and adhered to together, owned by an organization so that the organization feels one family and creates a condition that members of the organization feel different from other organizations.

Mas'ud (2004), organizational culture is a system of meaning, values, and beliefs shared in an organization that is a reference for acting and differentiating one organization from another organization. The organizational culture then becomes the identity or the main character of the organization that is maintained and maintained.

Robbins (2003), states that organizational culture is a system of shared meanings shared by members of an organization that distinguishes the organization from other organizations. Organizational culture is a system of values obtained and developed by the organization and the basic habits and philosophies of its founders, which are formed into rules that are used as guidelines in thinking and acting in achieving organizational goals. A culture that grows to be strong can spur the organization towards better development.

\title{
Work Discipline
}

According to Fathoni (2006:172) explains the understanding of discipline from the perspective of human resource management, is: Discipline is the sixth operative function of Human Resource Management. Discipline is the most important operational function of Human Resource Management because of the better employee discipline, the higher the work performance achieved.

Fathoni (2009) said that discipline is one of the important operative functions because of the higher the discipline of an employee, the higher the work performance. Davis (in Mangkunegera,2011:129) argues that "discipline is management actions to enforce organization standards.

Furthermore, Sedarmayanti (2011:381) argues that the discipline of civil servants is discipline is a condition to make corrections or punish employees who violate the provisions or procedures established by the organization. Discipline is a form of control so that the execution of employees' work is always within the corridor of applicable laws and regulations.

In essence, discipline is compliant with the rules or orders set by the organization. In this case, discipline is a process used to deal with performance expectations; this process involves managers in identifying and communicating performance problems to employees.

\section{Organizational Citizenship Behaviour}

Organizational Citizenship Behavior (OCB) is behavior that is not part of the tasks that have been formally required for an employee but as a whole encourages the effective functioning of the organization (Robbins, 2003). In terms of organizational effectiveness, individuals in a team need to have supportive behavior. These behaviors are not only behaviors that are appropriate for their role (in the role) but are expected to be able to bring up the extra-role behavior of the individual so that the teamwork can be more solid and can work optimally for the organization (Khrisnan 2004). In addition to the above definition, Organ (2006) also gives five dimensions of Organizational Citizenship Behaviour (OCB):

1. Altruism: behavior that influences helping co-workers in their duties.

2. Conscientiousness: behavior that is part of employees who carry out tasks that exceed the minimum requirements.

3. Sportsmanship: the feeling of employees to refrain from complaints about things that are not liked.

4. Courtesy: behavior that is part of an individual to replace others in the organization about changes that affect their work.

5. Civic virtue: behavior that is part of individuals that indicates that they participate in the company. 
Organizational Behavior (OB) is a science that studies human behavior in an organization and how that behavior impacts the organization. One of the behaviors that give an impact is Organizational Citizenship Behavior (OCB) organizational citizenship behavior.

In the end, OCB becomes a variable in organizational behavior. Organ (2006) defines that OCB is the free behavior of individuals which is explicitly or indirectly recognized by the formal system and that functions effectively and efficiently in an organization.

In general, OCB is a behavior that makes an individual do something that is not described in his work and there is no reward or appreciation for his actions consciously and of his desires, such as helping coworkers do their jobs, or helping the boss even though outside the specified working hours. This behavior is behavior that can increase organizational effectivenes s.

\section{Organizational Performance}

According to Richard et al (2007) organizational performance is something that is produced by the organization which includes the results (outcomes) namely financial performance such as profit as measured by return on assets, return on investment and so on, market performance (product market performance ) such as market share expansion, and sales. Besides, the return from the shareholder is the return of the shareholder and the economic growth of the shareholder.

In some areas, organizational performance can also be measured from other things such as strategic planning, operations, and finance, legal and organizational development. In developing institutions or organizations it is a must to survive in the competitive world climate.

The purpose of productivity is related to the development of the organization (Shrestha,1997). Small organizations have a desire to continue to grow and become big. The developing organization is in the context of communicating the development itself.

Measuring organizational performance according to the PBM SIG (the performance-based management special interest group concept) is by monitoring and reporting the program being run, and paying attention to the objectives achieved. The measured performance is based on the process of activities in the program being run, products produced, and services Besides, according to Kaplan and Norton (1992) organizational performance should be measured not only in terms of financial concepts but also from non-financial performance can be measured in terms of productivity, quality, consistency, etc. On the other hand organizational performance measures results, behavior levels and normative, education and concepts produced including management development (Richard, 2002).

\section{Research Methods}

\section{Research Design}

This study uses an explanatory analysis approach. This means that each variable presented in the hypothesis will be observed through testing the causal relationship of the independent variable to the dependent variable. The relationship between variables can be described in the form of path analysis diagram as follows:

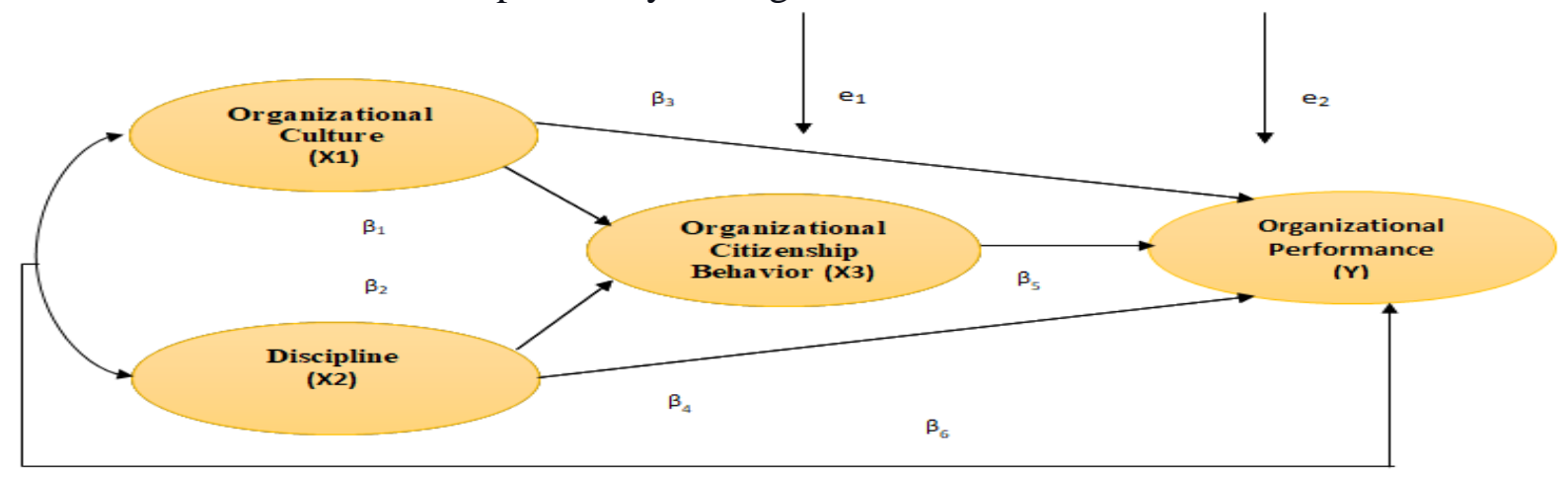

Figure 1. Overall Path Analysis 


\section{Object of Research}

The study was conducted by an inspectorate employee of Bekasi City, having its address at Jl. Rawa Tembaga I, No. 1, Bekasi, West Java Postal Code 17141

\section{Population and Research Samples}

The population is a generalization area consisting of objects/subjects that have certain quantities and characteristics determined by researchers to be studied and then conclusions are drawn (Sugiyono, 2013). The sample is pulling a portion of the population to represent the entire population (Surakhmad, 2010).

The total number of employees is 86 employees. All of these employees were involved in this study so that the sampling using the saturated model.

\section{Research Results and Discussion}

\section{The Effect of Organizational Culture and Discipline on Organizational Performance}

The linear analysis model can be seen based on calculations using the SPSS program as follows.

\section{Table1. Results of the first equation analysis}

\section{Coefficients $^{\mathrm{a}}$}

\begin{tabular}{|c|c|c|c|c|c|c|}
\hline & \multirow[b]{2}{*}{ Model } & \multicolumn{2}{|c|}{ Unstandardized Coefficients } & \multirow{2}{*}{$\begin{array}{c}\text { Standardized } \\
\text { Coefficients } \\
\text { Beta }\end{array}$} & \multirow[b]{2}{*}{$\mathrm{t}$} & \multirow[b]{2}{*}{ Sig. } \\
\hline & & $\mathrm{B}$ & Std. Error & & & \\
\hline \multirow[t]{3}{*}{1} & (Constant) & 17,307 & 2,623 & & 6,597 &, 000 \\
\hline & CULTURE & ,696 & ,116 & ,431 & 5,981 & 000 \\
\hline & DISCIPLINE & ,546 & ,067 & 584 & 8,097 & ,000 \\
\hline
\end{tabular}

a. Dependent Variable: PERFORMANCE

Based on the above table, the simultaneous structural equation can be described as follows $\mathrm{Y}=0,431 \mathrm{X} 1+0,584 \mathrm{X} 2$

Table 2. F value Calculate simultaneous equations

ANOVA $^{\mathrm{a}}$

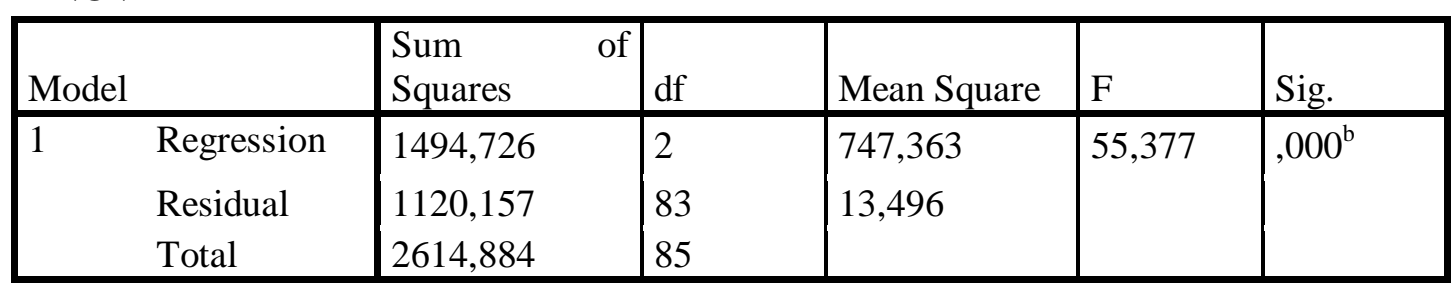

a. Dependent Variable: PERFORMANCE

b. Predictors: (Constant), DISCIPLINE, CULTURE

Based on the table above it is known that the calculated $F$ value of 55.377 and a significance of 0.00 . This value is smaller than 0.05. This means that organizational culture and discipline variables influence simultaneously organizational performance. The magnitude of the effect of independent variables on the dependent variable can be seen from the value of $r$ squared as follows. 


\section{Model Summary}

Table 3. The value of $r$ squared of the first regression model

\begin{tabular}{|l|l|l|l|l|l|}
\hline Model & $\mathrm{R}$ & R Square & $\begin{array}{l}\text { Adjusted } \\
\text { Square }\end{array}$ & $\begin{array}{l}\text { Std. Error of the } \\
\text { Estimate }\end{array}$ & Durbin-Watson \\
\hline 1 &, $756^{\mathrm{a}}$ &, 572 &, 561 & 3,67367 & 1,238 \\
\hline
\end{tabular}

a. Predictors: (Constant), DISCIPLINE, CULTURE

b. Dependent Variable: PERFORMANCE

Based on the table above it is known that the value of $r$ squared of $57.2 \%$ means that organizational culture and discipline variables affect the performance of the organization by $57.2 \%$ while the rest is influenced by other variables not included in the equation model.

\section{Analysis of the Effect of Organizational Culture on Organizational Performance}

The results of the analysis of the influence of organizational culture on performance partially can be seen in the following table.

\section{Table 4. Results of the analysis of the second regression equation}

\begin{tabular}{|c|c|c|c|c|c|c|}
\hline \multicolumn{7}{|c|}{ Coefficients $^{\mathrm{a}}$} \\
\hline \multirow{2}{*}{\multicolumn{2}{|c|}{ Model }} & \multicolumn{2}{|c|}{ Unstandardized Coefficients } & \multirow{2}{*}{\begin{tabular}{|l}
$\begin{array}{l}\text { Standardized } \\
\text { Coefficients }\end{array}$ \\
Beta
\end{tabular}} & \multirow[b]{2}{*}{$\mathrm{t}$} & \multirow[b]{2}{*}{ Sig. } \\
\hline & & B & Std. Error & & & \\
\hline 1 & $\begin{array}{l}\text { (Constant) } \\
\text { CULTURE }\end{array}$ & $\begin{array}{l}27,377 \\
, 779\end{array}$ & $\begin{array}{l}3,072 \\
154\end{array}$ & , 483 & $\begin{array}{l}8,912 \\
5,055\end{array}$ & $\begin{array}{l}, 000 \\
, 000\end{array}$ \\
\hline
\end{tabular}

a. Dependent Variable: PERFORMANCE

The structural equation from the data above can be seen as follows $\mathrm{Y}=0.483 \mathrm{X} 1$

Based on the table of analysis results above it is known that the coefficient of organizational culture is 0.483 . $T$ value of 5.055. The significance value is 0.00 . This significant value is smaller than 0.05 . This means that organizational culture variables partially affect organizational performance. The magnitude of the influence of organizational culture on organizational performance can be seen in the following table.

Table 5. The value of $r$ squared for the second equation

Model Summary
\begin{tabular}{|l|l|l|l|l|}
\hline Model & R & R Square & Adjusted R Square & $\begin{array}{l}\text { Std. Error of the } \\
\text { Estimate }\end{array}$ \\
\hline 1 &, $483^{\mathrm{a}}$ &, 233 &, 224 & 4,88553 \\
\hline
\end{tabular}

a. Predictors: (Constant), CULTURE

Based on the table above can be seen the value of $r$ squared of 0.233 . This means that the influence of organizational culture variables on performance by $23.3 \%$ and the rest is influenced by other variables not included in the equation model.

\section{Analysis of the Effect Influence of Discipline Analysis on Organizational Performance}

The results of the analysis of the effect of discipline on partial performance can be seen in the following table. 


\section{Coefficients $^{\mathrm{a}}$}

Table 6. Results of the analysis of the third regression equation

\begin{tabular}{|c|c|c|c|c|c|}
\hline \multirow[b]{2}{*}{ Model } & \multicolumn{2}{|c|}{$\begin{array}{l}\text { Unstandardized } \\
\text { Coefficients }\end{array}$} & \multirow{2}{*}{\begin{tabular}{|l} 
Standardized \\
Coefficients \\
Beta \\
\end{tabular}} & \multirow[b]{2}{*}{$\mathrm{t}$} & \multirow[b]{2}{*}{ Sig. } \\
\hline & B & Std. Error & & & \\
\hline $\begin{array}{ll}1 & \text { (Constant) } \\
& \text { DISCIPLINE }\end{array}$ & $\begin{array}{l}30,207 \\
.581\end{array}$ & $\begin{array}{l}1,776 \\
.080\end{array}$ & .622 & $\begin{array}{l}17,012 \\
7,282\end{array}$ & $\begin{array}{l}, 000 \\
.000\end{array}$ \\
\hline
\end{tabular}

a. Dependent Variable: PERFORMANCE

The structural equation from the data above can be seen as follows $\mathrm{Y}=0.622 \mathrm{X} 2$

Based on the table of analysis results above it is known that the coefficient of discipline is 0.622 . $\mathrm{T}$ value of 7.282. The significance value is 0.00 . This significant value is smaller than 0.05 . This means that the variable of discipline affects partially organizational performance. The amount of disciplinary influence on organizational performance can be seen in the following table.

Model Summary

Table 7. R-value for the third equation

\begin{tabular}{|l|l|l|l|l|}
\hline Model & $\mathrm{R}$ & R Square & Adjusted R Square & $\begin{array}{l}\text { Std. Error of the } \\
\text { Estimate }\end{array}$ \\
\hline 1 &, $622^{\mathrm{a}}$ &, 387 &, 380 & 4,36840 \\
\hline
\end{tabular}

a. Predictors: (Constant), DISCIPLINE

Based on the table above can be seen the value of $r$ squared of 0.387 . This means that the influence of disciplinary variables on organizational performance is $38.7 \%$ and the rest is influenced by other variables not included in the equation model.

\section{Analysis of the Effect of Organizational Citizenship Behavior on Organizational Performance}

The results of the analysis of the effect of organizational citizenship behavior partially on organizational performance can be seen in the following table.

\section{Table 8. Results of the fourth regression equation analysis}

\section{Coefficients $^{\mathbf{a}}$}

\begin{tabular}{|c|c|c|c|c|c|}
\hline \multirow[b]{2}{*}{ Model } & \multicolumn{2}{|c|}{$\begin{array}{l}\text { Unstandardized } \\
\text { Coefficients }\end{array}$} & \multirow{2}{*}{$\begin{array}{l}\text { Standardized } \\
\text { Coefficients } \\
\text { Beta } \\
\end{array}$} & \multirow[b]{2}{*}{$\mathrm{t}$} & \multirow[b]{2}{*}{ Sig. } \\
\hline & $\mathrm{B}$ & Std. Error & & & \\
\hline $\begin{array}{ll}1 & \text { (Constant) } \\
& \text { OCB }\end{array}$ & $\begin{array}{l}9,912 \\
, 781\end{array}$ & $\begin{array}{l}2,231 \\
, 053\end{array}$ &, 851 & \begin{tabular}{|l|}
4,442 \\
14,834
\end{tabular} & $\begin{array}{l}, 000 \\
, 000\end{array}$ \\
\hline
\end{tabular}

a. Dependent Variable: PERFORMANCE

The structural equation from the data above can be seen as follows $\mathrm{Y}=0.851 \mathrm{X} 3$

Based on the table of analysis results above it is known that the coefficient of organizational citizenship behavior is 0.851 . $\mathrm{T}$ value of 14.834 . The significance value is 0.00 . This significant value is smaller than 0.05 . This means that organizational citizenship behavior variables partially affect organizational performance. The amount of influence of organizational citizenship behavior on organizational performance can be seen in the following table. 


\section{Table 9. $R$ value for the fourth equation}

Model Summary

\begin{tabular}{|l|l|l|l|l|}
\hline Model & $\mathrm{R}$ & R Square & Adjusted R Square & $\begin{array}{l}\text { Std. Error of the } \\
\text { Estimate }\end{array}$ \\
\hline 1 &, $851^{\mathrm{a}}$ &, 724 &, 720 & 2,93262 \\
\hline
\end{tabular}

a. Predictors: (Constant), OCB

Based on the table above can be seen the value of $r$ squared of 0.724 . This means that the influence of organizational citizenship behavior variables on organizational performance by $72.4 \%$ and the rest is influenced by other variables not included in the equation model.

\section{Analysis of the Effect of Organizational Culture on Organizational Performance through Organizational Citizenship Behavior Variables}

Based on the partial path analysis above, it can be described as follows. The analysis is an analysis of the pathway with the following substructural images.

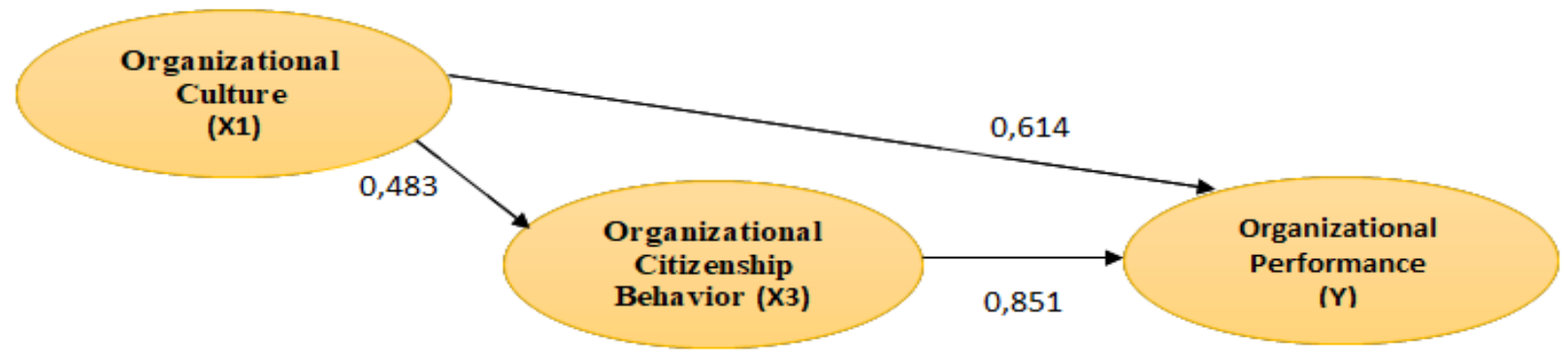

Figure 2. Path analysis of the effect of X1 on Y through X3

The coefficient of influence of organizational culture on organizational citizenship behavior can be seen in the following table

Table 10. Effects of organizational culture on organizational citizenship behavior

\begin{tabular}{|c|c|c|c|c|c|c|}
\hline \multicolumn{7}{|c|}{ Coefficients $^{\mathrm{a}}$} \\
\hline \multirow{2}{*}{\multicolumn{2}{|c|}{ Model }} & \multicolumn{2}{|c|}{ Unstandardized Coefficients } & \multirow{2}{*}{\begin{tabular}{|l}
$\begin{array}{l}\text { Standardized } \\
\text { Coefficients }\end{array}$ \\
Beta \\
\end{tabular}} & \multirow[b]{2}{*}{$\mathrm{t}$} & \multirow[b]{2}{*}{ Sig. } \\
\hline & & $\mathrm{B}$ & Std. Error & & & \\
\hline 1 & $\begin{array}{l}\text { (Constant) } \\
\text { CULTURE }\end{array}$ & \begin{tabular}{l|}
20,777 \\
1,079
\end{tabular} & $\begin{array}{l}3,018 \\
151\end{array}$ & 614 & $\begin{array}{l}6,885 \\
7,127\end{array}$ & $\begin{array}{l}, 000 \\
, 000\end{array}$ \\
\hline
\end{tabular}

a. Dependent Variable: OCB

Based on the picture above it can be seen that the influence of organizational culture on organizational performance is 0.483. The influence of organizational culture on organizational performance through organizational citizenship behavior is $0.614 \times 0.851=0.5191$. In this case, the indirect effect is greater than the direct effect so it can be said that the variable of organizational citizenship behavior as an intervening variable.

6. Analysis of the Effect of Discipline on Organizational Performance through Organizational Citizenship Behavior Variables 
Based on the partial path analysis above, it can be described as follows. The analysis is an analysis of the pathway with the following substructural images.

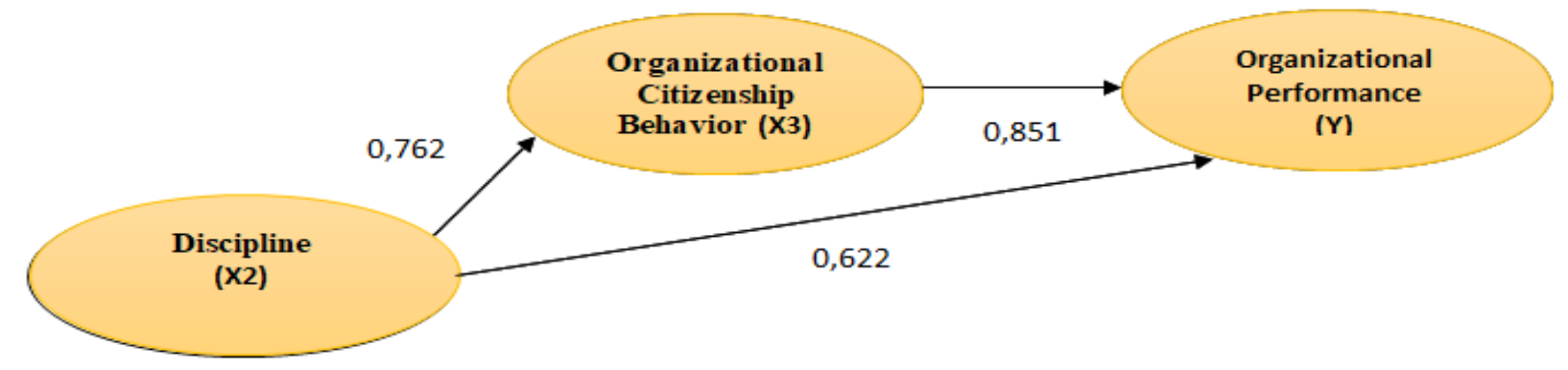

table.

Figure 3. Path analysis of the effect of X2 on Y through X3

The value of the coefficient of discipline on organizational citizenship behavior can be seen in the following

Table 11. Coefficient values of the effect of Discipline on the organizational citizenship behavior of work Coefficients $^{\mathrm{a}}$

\begin{tabular}{|c|c|c|c|c|c|}
\hline \multirow[b]{2}{*}{ Model } & \multicolumn{2}{|c|}{ Unstandardized Coefficients } & \multirow{2}{*}{\begin{tabular}{|l|}
$\begin{array}{l}\text { Standardized } \\
\text { Coefficients }\end{array}$ \\
Beta \\
\end{tabular}} & \multirow[b]{2}{*}{$\mathrm{t}$} & \multirow[b]{2}{*}{ Sig. } \\
\hline & $\mathrm{B}$ & Std. Error & & & \\
\hline $\begin{array}{ll}1 & \text { (Constant) } \\
& \text { DISCIPLINE }\end{array}$ & $\begin{array}{l}25,315 \\
, 777\end{array}$ & $\begin{array}{l}1,599 \\
, 072\end{array}$ &, 762 & $\begin{array}{l}15,831 \\
10,799\end{array}$ & $\begin{array}{l}, 000 \\
, 000\end{array}$ \\
\hline
\end{tabular}

a. Dependent Variable: OCB

Based on the picture above it can be seen that the direct influence of discipline on organizational performance is 0.622 . While the effect of discipline on organizational performance through organizational citizenship behavior is $0.762 \times 0.851=$ 0.648. In this case, the direct effect is smaller than the indirect effect so it can be said that the variable of organizational citizenship behavior as an intervening variable.

\section{Conclusions and Recommendations}

\section{Conclusion}

Organizational culture variables and disciplines affect simultaneously organizational performance. The value of $r$ squared is $57.2 \%$ which means that organizational culture and discipline variables affect the performance of the organization by $57.2 \%$ while the rest is influenced by other variables not included in the equation model.

Organizational culture variables affect organizational performance partially. T value of 5.055. The significance value is 0.00. This significant value is smaller than 0.05. The value of $r$ squared is 0.233 . This means that the influence of organizational culture variables on performance by $23.3 \%$ and the rest is influenced by other variables not included in the equation model.

Discipline variables partially affect organizational performance. T value of 7.282 . The significance value is 0.00 . This significant value is smaller than 0.05 . The value of $r$ squared is 0.387 . This means that the influence of disciplinary variables on organizational performance is $38.7 \%$ and the rest is influenced by other variables not included in the equation model.

The variable of organizational citizenship behavior partially influences organizational performance. T value of 14.834 . The significance value is 0.00 . This significant value is smaller than 0.05 . The value of $r$ squared is 0.724 . This means that the influence of organizational citizenship behavior variables on organizational performance by $72.4 \%$ and the rest is influenced by other variables not included in the equation model. 
The influence of organizational culture on organizational performance is 0.483 . The influence of organizational culture on organizational performance through organizational citizenship behavior is $0.614 \times 0.851=0.5191$. In this case, the indirect effect is greater than the direct effect so it can be said that the variable of organizational citizenship behavior as an intervening variable.

The direct effect of discipline on organizational performance is 0.622 . While the effect of discipline on organizational performance through organizational citizenship behavior is $0.762 \times 0.851=0.648$. In this case, the direct effect is smaller than the indirect effect so it can be said that the variable of organizational citizenship behavior as an intervening variable.

\section{Recommendations}

Organizational performance needs to be improved by increasing the understanding and practice of organizational culture and increasing employee discipline. Improving organizational performance can also be done by improving organizational culture. Organizational culture is defined as the values, beliefs, and principles that serve as the basis for an organization's management system as well as management practices and behaviors that help and strengthen basic principles. This can be improved by paying more attention and understanding to the organization's mission, consistency, and adaptability and employee engagement in the organization.

Improved work discipline also needs to be done by complying with applicable rules, working on time and caring for the rules that have been made.

Improving organizational performance also needs to be improved organizational citizenship behavior. This is done by helping fellow employees even though it is outside the duties of the employee.

\section{References}

(1) A.F.Stoner James, DKK, 1996, Manajemen , Edisi Indonesia, Penerbit PT. Prenhallindo, Jakarta.

(2) Abdurrahmat Fathoni, 2009 “ Organisasi dan Manajemen Sumber Daya Manusia” Jakarta : Rineka Cipta.

(3) Baron \& Greenberg. 1997. Behavior in Organization Understanding and Managing The Human Side of Work. 6th edition. USA: Prentice-Hall.

(4) Daft, Richard L. 2002. Manajemen Edisi Kelima Jilid Satu. Jakarta : Erlangga.

(5) Dessler, Gary. 2006. Manajemen Sumber Daya Mnusia Jilid 1. Jakarta : PT. Indeks.

(6) Fuad Mas'ud, 2004, "Survai Diagnosis Organisasional,” Badan Penerbit Universitas Diponegoro, Semarang.

(7) Kaplan, R. S., \& Norton, D. P. 1992. The Balanced Scorecard - Measures That Drive Performance. Harvard Business Review.

(8) Krishnan, V.R. 2004. Impact of transformational leadership on followers' influence strategies. The Leadership \& Organization Development Journal. Vol. 25 No. 1. 58-72.

(9) Luthans, Fred. 2011. Organizational Behavior: An Evidence-Based Approach. New York: McGraw-Hill.

(10) Mangkunegara. 2011. Manajemen Sumber Daya Perusahaan. PT . Remaja Rosdakarya. Bandung.

(11) Organ, Dennis W., et.al. 2006 Organizational Citizenship Behavior. Its Nature, Antecedents, and Consequences. California: Sage Publications, Inc.

(12) Richard Kathrins. 2007. The Relationship of Leadership Style and Types of Organizational Cultures to the Effectiveness and Employee Satisfaction in Acute Care Hospital. Dissertation. Faculty of the College of Business Administration Of Touro University International

(13) Robbins, P. Stephen. 2003. Perilaku Organisasi. Edisi Sembilan, Jilid 2. Edisi Bahasa Indonesia. PT Indeks Kelompok Gramedia, Jakarta.

(14) Sedarmayanti. 2011. Manajemen Sumber Daya Manusia. Reformasi Birokrasi dan Manajemen Pegawai Negeri Sipil, Cetakan Kelima, PT Refika Aditama, Bandung.

(15) Shrestha, Taliziduhu, 1997. Metodologi Ilmu Pemerintahan. Jakarta: Rineka Cipta.

(16) Sugiyono. 2013. Metode Penelitian Manajemen. Bandung : Alfabeta.

(17) Winarno Surakhmad. 2010. Pengantar Penelitian Ilmiah Dasar Metode Teknik. Bandung: Tarsito. 